cursory study of Spenser's work, it may be that in this brief note we have the evidence of another kind of influence, one that provided for him a justification for his own dancing attendance at the court of public acclaim.

Hofstra University

JoANN PECK KRIEG

\title{
NOTES
}

1 Walt Whitman, The Complete Writings of Walt Whitman, ed. Richard M. Bucke, Thomas B. Harned, and Horace L. Traubel (New York and London: G. P. Putnam's Sons, 1902), 9:119.

2 See Emory Holloway, ed., Uncollected Poetry and Prose of Walt Whitman (Garden City, N.Y.: Doubleday, 1921), 1:128n. A search of Whitman's reviews during his tenure as editor of The Brooklyn Daily Eagle has failed to substantiate Holloway's claim that Whitman reviewed the book.

3 Floyd Stovall, The Foreground of Leaves of Grass (Charlottesville: University of Virginia Press, 1974), p. 234.

4 The Complete Writings of Walt Whitman, 10:83, No. 310.

5 "America and the Early English Poets," The United States Democratic Review, V (May 1839), p. 469.

6 The Complete Writings of Walt Whitman, 9:77.

7 Ibid.

\section{RICHARD SELZER: POET OF THE BODY AND POET OF THE SOUL}

Rarely has the spirit of Whitman breathed so freely as it does through the recent writings of poet-physician Richard Selzer. ${ }^{1}$ Selzer never invokes Whitman's name, but his presence is felt everywhere: in Selzer's quest for the "exact location of the soul," in his "Pages from a Wound-Dresser's Diary," in his robust reverence of the body ("I love the solid heft of men as much as I adore the heated capaciousness of women"), and in phrases casually dropped here and there ("Out of this pelvis, endlessly rocking, drops man").

Whitman himself was not one to shrink from disease, peering deeply, intently at the rheumatic, the consumptive, the insane, the wounded:

I do not ask the wounded person how he feels, I myself become the wounded person,

My heart turns livid as I lean on a cane and observe. ${ }^{2}$

Dr. Selzer, too, is ever observing. "I spy on my patients," he writes in "The Discus Thrower." "Ought not a doctor to observe his patient by any means and from any stance? So I stand in the doorways of hospital rooms and gaze." ${ }^{3}$ It is Dr. Selzer's penetrating eye which most draws us-probing the inner secrets of the body, gazing 
on those shortly to die, peering at wounds which are at once devouring and ennobling. Selzer is no mere surgeon, but a poet. "The poet is the only true doctor," he admits, quoting Emerson. "It is the poet who heals with his words, staunches the flow of blood, stills the rattling breath, applies poultice to the scalded flesh." 4 Selzer is everywhere referring to poets, but it is to Whitman's great themes he gives fullest expression - to the body and the soul, mortality and immortality, the two problems ever intertwined - "O living always, always dying."

As Whitman's palms cover continents, Selzer palms the landscape of the body. Man is a microcosm, he reminds us, "representing in all his parts the earth, perhaps the universe." And in Mortal Lessons he takes us on a journey through those parts-mapping the primitive depths of the belly, reading our history in bone, reflecting upon the growth of a stone, celebrating the regenerative power of liver. It is a quest for the soul, forever eluding our grasp, yet glimpsed everywhere. These pieces are "mortal lessons," yet breathe of wonder and mystery and immortality. It is this that makes Selzer a poet. "So shall I make of my fingers, words; of my scalpel, a sentence; of the body of my patient, a story." 5 And the fulfillment of his aim resonates with Whitman's more august ambition:

I will make the poems of materials, for I think they are to be the most spiritual poems,

And I will make the poems of my body and of mortality

For I think I shall then supply myself with the poems of my soul and of immortality. ${ }^{6}$

Dr. Selzer is most overtly Whitmanian in his "Pages from a Wound-Dresser's Diary." It begins:

I am a dresser of wounds.

My name is William. My beard is grayer than it is black, but I am childless.

I make my rounds on the decks of the steamboat Fanuary.

I dress the farmers who make up the regiments of Tennessee, Ohio, and Kentucky. ${ }^{7}$

These pages are everywhere redolent with the Whitman of Specimen Days-from the opening catalogue of observations, to the graphic details of the wounds, to the "urgent whispers of love" from the lips of the wounded. Yet I think this is no mere imitation. Rather, through reading Selzer, we are made ever more conscious of how the art of poetry and the art of healing spring from a common source.

And from reading Selzer, one will naturally return to Whitman with an added dimension. One may hear more keenly "the hiss of the surgeon's knife, the gnawing teeth of his saw"; or sense more deeply how "the physician after long putting off gives the silent and terrible look for an answer"; or understand more clearly why Whitman so often uses illness and disease and wounds as metaphors (“. . probably every spear of grass rises out of what was once a catching disease"). ${ }^{8}$ As for Selzer, the richness one finds in his work is his view of humanity-as individuals, as a race. "So much of a race depends on how it faces death, and how it stands personal anguish 
and sickness," wrote Whitman in Specimen Days. ${ }^{9}$ These perspectives Selzer presents to us again and again; and what emerges is a new reminder of man's greatness and strength and magnanimity and divinity-perspectives we cannot afford to lose.

Gustavus Adolphus College

Thomas BeCKNell

\section{NOTES}

1 Mortal Lessons: Notes on the Art of Surgery (New York: Simon and Schuster, 1976); Rituals of Surgery (New York: Simon and Schuster, 1974); Confessions of a Knife (New York: Simon and Schuster, 1979).

2 "Song of Myself," 11. 845-846, (1892).

3 Confessions of a Knife, p. 27.

4 Mortal Lessons, pp. 16, 23.

5 Mortal Lessons, p. 25.

6 "Starting from Paumanok," 11. 71-73.

7 Confessions of a Knife, p. 133.

8 "Song of Myself," 1. 942; "To Think of Time," 1. 15; "This Compost," 1. 41.

9 Prose Works 1892, ed. Floyd Stovall (New York: New York University Press, 1963), 1:116.

\section{WHITMAN IN CHINA}

Gay Wilson Allen concludes his discussion of "Walt Whitman and World Literature" in The New Walt Whitman Handbook with a paragraph on Whitman in the People's Republic of China. ${ }^{1}$ As Professor Allen points out, Chinese readers have had access to a substantial sampling of Whitman's poems for several decades. Chu T'u-nan, an important member of the Communist Party and an advocate of cultural exchange, began translating Whitman's poetry after 1930. Over the next twentyfive years he translated fifty-eight of Whitman's poems, including "Song of Myself," "Crossing Brooklyn Ferry," "The Sleepers," the "Lilacs" elegy and "I Sing the Body Electric." In 1955 these were collected in a 324-page volume which contained about one-fourth of Whitman's total output. In reviewing this book, Angela C. J. Palandri found it generally accurate but noted that some passages were altered to make Whitman's poetry conform to Chinese politics. ${ }^{2}$

Chu's important pioneering effort is now being superseded by a new translation by Chao Lo-jui, an experienced translator and one of China's foremost scholars of American literature. In 1937 Professor Chao translated "The Waste Land" by T. S. Eliot. During the late 1940s, while her husband was a visiting professor at the Oriental Institute of the University of Chicago, she received a Chicago M.A. and Ph.D., writing her dissertation on Henry James. In 1949 she returned to Peking, perhaps the only Chinese citizen with a Ph.D. emphasizing American literature, and began 